\title{
Urinary Tract Hemorrhage
}

National Cancer Institute

\section{Source}

National Cancer Institute. Urinary Tract Hemorrhage. NCI Thesaurus. Code C78336.

Bleeding originating from any part of the urinary system. 